Tチューブを用いた瘻孔延長術にて治癒した難治性小腸皮膚癭の 1 例

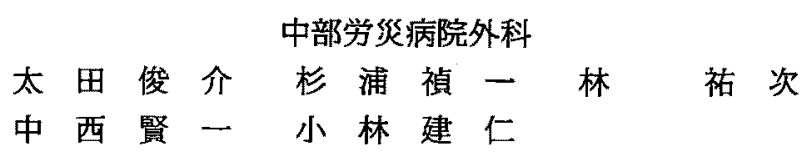

難治性小腸瘦に対し，Tチューブを用いた瘦孔延長術を行い治瘾しえたので報告す

る. 症例は54歳, 男性. 仙骨漫潤を伴う会陰部皮庙癌で, 会陰部切除, 腹会陰式直腸切 断術, S 3 以下の仙骨合併切除および腹直筋有茎皮弁を用いた会陰再建を行った。術後 2 カ月に仙腸関節炎を合併して小腸皮庙㿉を生じたが瘦孔が1.5cm しかなく，3カ月間保 存的に加療したが改善しなかった，Tチューブを用いて瘦孔延長術を行ったところ，1 カ月で瘦孔は治瘜した。

柬引用語：難治性小腸瘦, 瘦孔延長術, $\mathrm{T}$ チューブ

\section{緒 言}

難治性消化管㿋は発生頻度は多くないものの, 長期 間の入院を必要とし, 保存的治療か外科的治療加の方 針決定に悩むことがしばしばある. 今回われわれは, Tチューブを用いた瘦孔延長術を行い, 保存的に治癒 しえた難治性小腸瘦を経験したので報告する。

$$
\text { 症例 }
$$

患者: 54 歳, 男性.

既往歴：38年前, 外傷性脊佮㨁損傷 (Th12以下), 36年 前より仙骨部䄍創.

現病歴: 平成 9 年 4 月仙骨袮創部感染性㪚胞を切除 し, 病理診断は epidermal cystであった，その後裖創 部の感染を繰り返し, 仙尾部に皮庙硬結と膿愓形成を 記めたため, 平成11年 9 月切開・排膿と生検を行い, 扁平上皮癌と診断された。

現症：仙尾部から肛門近傍までの広範囲な皮席およ び皮下硬結を認め, 膿湟切開により深い皮庙潰瘍を形 成している(図 1 )。

MRI 検查：肛門背㑡および仙尾部背側皮下に high intensity massを認める. S 3 S 4 の仙骨前面にも high intensity mass 㒛め, 仙骨漫潤を想めた（図 1 ).

手術：平成11年10月19日, 会陰部 - 仙尾部切除, 腹

2002年11月11日受付 2003 年 2 月 7 日採用

〈所属施設住所〉

T455-8530 名古屋市港区港明 $1-10-6$
会陰式直腸切断術, 仙骨合併切除 (S 3 以下) および腹 直筋有茎皮弁による会陰形成術を行った。

術後経過：術後会陰創の感染および創哆開を合併し たが，比較的経過は順調で術後 8 日目より食事を開始 した。 12 月 3 日，腸閉塞を併発したが，保存的に軽快 した. 12月20日から高熱が続き，敗血症を併発した。 MRI 検查で仙腸関節炎と診断し，抗生剤投与を開始し たが，平成12年12月29日より臂部哆開創より便汁の流 出を認めた。

骨盤 CT 検査：仙腸関節が完全に離開している（図 2 ).

疾孔造影：潈孔造影を行うと仙骨断端部で小腸が造 影され，小腸瘦と診断した. 創哆開部の 2 次口から 1 次口までの距雕はわずか $1.5 \mathrm{~cm}$ しかなかったため,ド レーンは留置しなかった（図 3 )。仙骨断端部に瘑着し ていた小腸に仙腸関節の炎症が波及し，仙骨断端の機 械的刺激も加わって小腸壁が穿孔したものと考えられ た.

経過：絶食, 高カロリー輸液で保存的に経過観察し た．血液凝固因子第XIII因子製㓣も投与したが，腸夜 污染のために創哆開は改善せず 3 カ月が経過した.

瘄孔延長術：平成13年 3 月 2 日 Tチューブを用い た㿉孔延長術を施行した。 2 次的と 1 次口の間が1.5

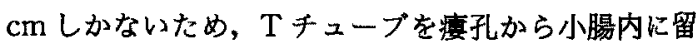
置後，皮下トンネルを作り，等部外側へチューブを誘 導・固定して 2 次口の位置を変更して湄孔を延長した (図 4). 


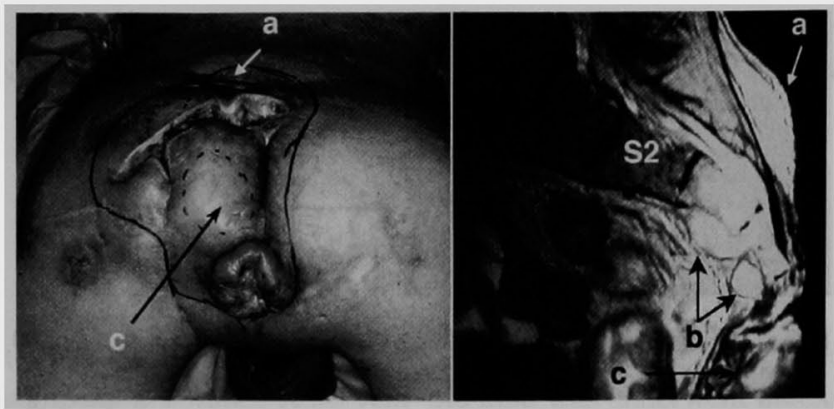

図 1 術前所見：左）部～会陰部所見，右) MRI：皮间溃瘍周囲加 ら仙尾部(a)および会陰部(c)に腫疡が広がり，第 3 , 第 4 仙骨前面に 進展している(b).

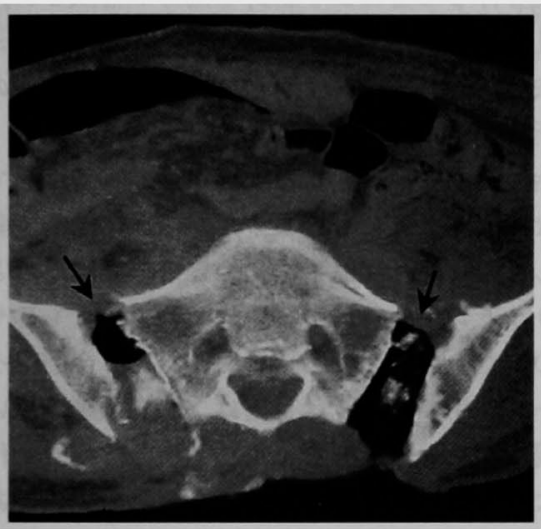

图 2 骨盤 CT：仙腸関節が完全に離開して いる.

表孔延長術後の経過：廈孔延長術後 10 日で旧 2 次口 からの腸液漏出は止まり，創の肉芽形成も順調て創は 徐々に埋まった(図 5 ). 約 1 力月後には旧 2 次口は上 皮化したため, 術後40日目に Tチューブを抜去したと ころ,翌日には新しい瘦孔からの腸液の流出は減少し， 6 日後には腸夜の流出は止まり痽孔は閉鎖した。

\section{考察}

消化管璂は外傷性，炎症性，壤死性，腫場性などさ まざまな原因から起こるが，原疾患，初回術式，消化 管算の存在部位，形態，走行により，その治療方針は 大きく左右される。しかし，腹膜炎あるいは脹鸤を併 発した場合を除いて，治療の第一歩は十分なドレナー ジのもとでの栄管理を中心とした保存的治療であ る”. 鹰孔の自然閉鎖率は部位によって異なり，胃十二 指腸は $30 \sim 78 \%$, 小腸は $4 \sim 63 \%$, 大腸は $27 \sim 100 \%$ と 報告されているが，上部消化管は難治性樭孔となるこ とが多い2．難治性となった場合, いつまで保存的に加
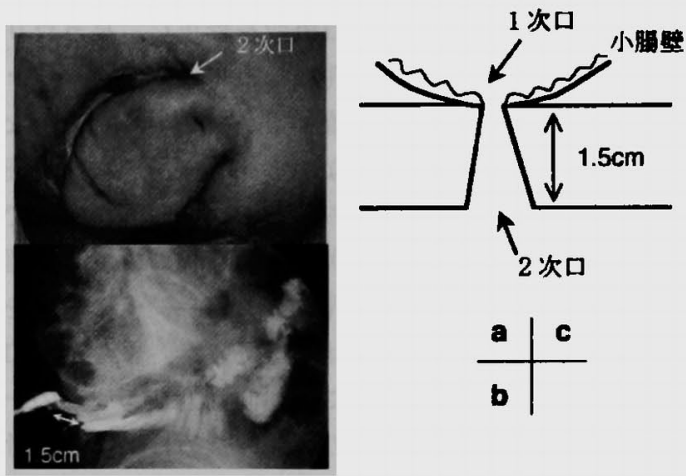

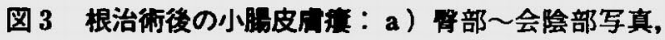
b）瘦孔造影，c）シェーマ.
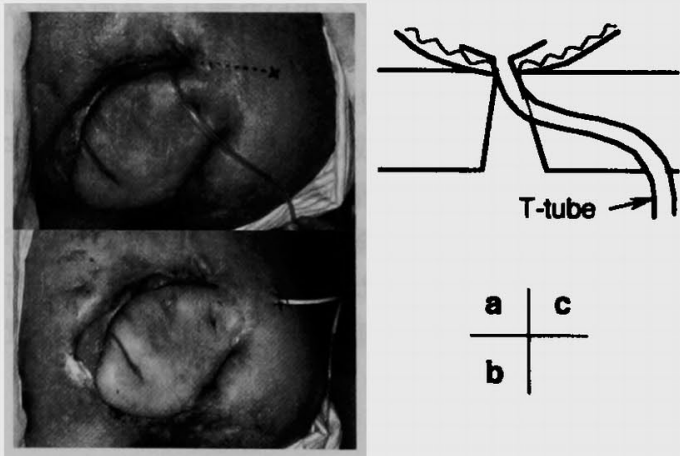

図4瘄孔延長術：a）2 次口より し, ×部に 2 次口を㚆更する. b) 新しい 2 次口に $\mathrm{T}$ チ

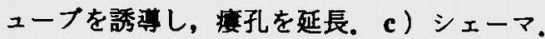

療するのか, いつ手術的に治療するかどうかの判断を せまられることになる。

本例では仙腸関節が炎症により離開し，仙骨断端に 痹着していた小腸に炎症が波及したため穿孔し，腸㿉 


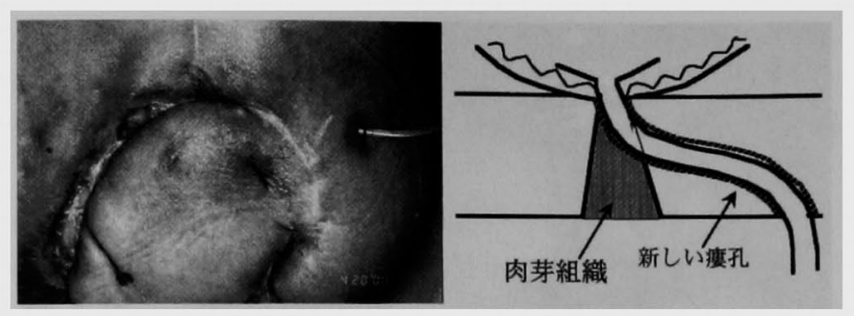

图 5 搌孔延長術後：左)旧 2 次口からの腸夜漏出は止まり，創は肉 芽組䢂で埋まった. 右) シェーマ.

を形成したものと考えられた，原因は小腸周囲への炎 症の波及によるものであり，炎症がおさまれば腸瘦も 改善すると期待して保存的に加療した。

保存的治療は原則的に経口捸取を禁止し，高カロリ 一輸液 (IVH) を行う。瘦孔にそってネラトンやファ イコンなどのドレーンを留置して, 洗浄や持続吸引な どを行い, 適宜瘦孔造影しながらドレーンを次第に細 く，短くして瘦孔閉鎖に持ち込むのが一般的な方針で ある3!. 今回の症例では, 1 次口から 2 次口まての距離 が $1.5 \mathrm{~cm}$ と極めて短く，度孔にドレナージチューブを 㨉入し徐々に浅くする試みは困難だった。また 1 次口 は仙骨断端に空着した小腸にあり仙骨断端が瘦孔の一 部を成しているため，瘦孔の切除のためには第 2 仙骨 の切除が必要となる可能性が考えられ，仙骨前面への 強固な疮着も予想されたため，痖孔切除術による根治 手術を跣躇した， 3 力月間保存的に治療したが改善し なかったため， Tチューブを用いた瘦孔延長術を試み た.

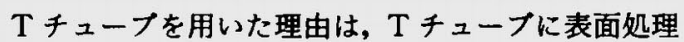
がされているため肉芽形成が期待できることと， T字 型のためにチューフの位置がずれにくいためである. 1 次口と 2 次口の距離が極めて短いため䇺孔の閉銷が 極めて困難と思われたため，2次口を別の離れた場所 に新たに作製して瘦孔を延長した。 Tチューブ留置
することで消化液との接触を抑えて旧璂孔の肉芽形成

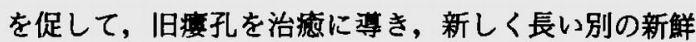
な瘦孔を作ることにより新鮮な肉芽が形成され，新し い痤孔が早期に治痹することを期待した， Tチューフ を抜去した後，短期間で新しい瘄孔が閉鎖したのは肉 芽が新鮮だったためと考えられる。

難治性消化管瘦に対するドレナージは各施設でさま さまな工夫がされているようだが，医中誌で文献的に 検索しても，瘦孔切除手術についての論文がほとんど であり,ドレナージについては教科書的なものや一般 論をのべたものしか検索できなかった. 今回行った T チューブを用いた瘦孔延長術は，瘦孔距離の短い難治 性小腸瘄に対し，瘦孔を延長して新たな掼孔を作るこ とにより㿉孔の治癁を図った全く新しい試みである。 本法は非常に有用であり, 瘦孔距離が短いため難治性 となっていると考えられる難治性消化管瘻症例に対し て試みる価値があると思われる。

\section{文献}

1）岡本健二, 大熊利忠：消化管隻患者の栄管理. 外科 $51: 40-45,1989$

2）長尾二郎，炭山嘉伸：難治性消化管瘦の手術. 手 術 $47: 1355-1360,1993$

3）中川原儀三, 小島靖彦, 野手雅幸 他 : 術後の難治 性㾴孔. 外科 $50: 110-114,1988$ 


\title{
ELONGATION METHOD FOR PERSISTENT EXTERNAL SMALL BOWEL FISTULA USING A T-TUBE - A CASE REPORT-
}

\author{
Shunsuke OHTA, Teiichi SUGIURA, Yuji HAYASHI, \\ Kenichi NAKANISHI and Kenji KOBAYASHI \\ Department of Surgery, Chubu Rosai Hospital
}

\begin{abstract}
We successfully treated a case of persistent external fistula of the small intestine by means of the elongation of the fistula using a T-tube. A 54-year-old man was underwent an excison of the perineum, anus and sacrum under the $3^{\text {rd }}$ sacral bone for perineal skin carcinoma. Reconstruction of the perineum was performed using an abdominal rectus muscle with skin. Two months after the operation, the patient had external small bowel fistula due to severe sacro-iliac arthritis. Conservative treatment for three months was ineffective, because the length of the fistula was only $1.5 \mathrm{~cm}$. We performed an elongation of the persistent fistula using a $\mathrm{T}$-tube. One month after the procedure, the fistula was cured.
\end{abstract}

